\title{
Symbolic Description of the Year Seasons in Uzbek Poetry
}

\author{
Zarnigor Sohibova, Dilrabo Quvvatova
}

\begin{abstract}
Eastern selected poetry took its long roots in literary description of year seasons. In X-XII century there were Uzbek literature examples, after that period in the works of our poets each season was compared to the human's life and had peculiar meaning with the description of the mental position of lyric hero. This article deals with defining symbolic meaning of spring and autumn in the poems of Alisher Navoiy and Abdulhamid Chulpon.
\end{abstract}

Keywords : symbolic meaning, selected poetry, modern poetry, tradition, lyric hero, imitation, metaphorical meaning.

\section{INTRODUCTION}

In classical oriental poetry, poems devoted to the seasons constitute a separate artistic system. Consequently, the discussion of "Winter and Summer" with the famous "Devoni Lugotit Turk" by Mahmud Kashghari, the "Spring Madness" by Yusuf Khos Hajib's "Kutadgu bilig", and also the poetry of Atai, Sakkoki, Lutfi, Eastern classical poetry. It is well known that the seasons are symbolic in literary works. We also find beautiful poems devoted to the seasons of poets like Mashrab, Munis, Komil Khorezmi, Nodira, Uvaysiy, Furkat.

This literary tradition continued in the original style of contemporary poets. Works of Alisher Navoiy, Chulpan, Abdulla Aripov can be examples.
Revised Manuscript Received on July 22, 2019.

Zarnigor Sohibova, A doctorate of Bukhara State University, Uzbekistan Dilrabo Quvvatova, A professor of Bukhara State University, Uzbekistan

\section{MATERIAL AND METHODS}

The poems of Uzbek poets, such as Alisher Navoi, Chulpon, Abdulla Aripov, and Tura Suleiman, were selected for the article. Comparative-typological, analytical methods were used in the coverage of the topic.

\section{DISCUSSION}

As you know, Alisher Navoi interpreted human life into four seasons of art. Famous parts of "Hazayin ul-Ma'ani" are symbolically named on this basis. The great poet's ghazals emphasize on the seasons of nature. We try to base our thinking on the case of the Spring and Autumn.

$$
\begin{aligned}
& \text { Бахор элга айшу манга изтироб, } \\
& \text { Кулуб холима, барку йиғлаб сахоб }[1,21 \text { б]. }
\end{aligned}
$$

It is well known that spring visiting after winter brings joy to the people. However, this season is bound to affect those who are suffering from love. The word "light" is lightning, lightning; the fire $[4,95]$ means "cloud" $[4,555]$. This state of mind is expressed in the form of spring clouds, rain, lightning and tamil art.

Бахору боғ сайридин не гул, не сарвдур комим,

Будур комимки, шояд учрағай сарви гуландомим

$$
[1,81] .
$$

In the ornaments, the poet believes that the purpose of the spring trek is not to see the beautiful nature, the flowers and the trees in it, but to meet the flower, the mistress. The spring reflects the embodiment of the spring flood.

Ғам хазонин зохир этмиш чехрайи зардим менинг,

Борғали елдек бахори нозпарвардим менинг $[1,69]$.

"The Treasure of Grief" represents the autumn. Autumn and pale yellow - the yellowness of the face is proportional The word "overseer" means "1,465." "Spring Nazparvard" depicts the image of a beloved mate.

Хар бири юз миннат айларлар, эрур бу хам жафо, Юз-у зулфунг даврида мундоқ кечар ёз-у қишим $[1,80]$.

It is known that he lives in a love affair. The poet points to

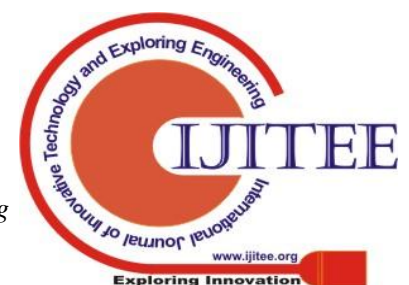




\section{SYMBOLIC DESCRIPTION OF THE YEAR SEASONS IN UZBEK POETRY}

this, insisting that the lover's "summer and winter" means that his whole life will be in the pursuit of love. It is worth noting that the poems of Alisher Navoi, whose artistic interpretation of the spring and fall seasons, are mainly reflected in the emotional state of the lover and the lover. Because the fall image depicts a love affair with the Hegira, and the lines about spring reflect the beauty of human life and love. Symbolic interpretations of the seasons in the Alisher Navoi ghazal have continued in contemporary Uzbek poetry.

After all, "the poet refers to the seasons of nature, describing the pain of the times, the sad and sad moods of his contemporaries, and sometimes the passionate feelings" [5, 111]. His poems like "Early Spring", "Autumn", "More Snow", "Before the Winter", "Spring Comes", and "Khazan" attract readers' attention. Therefore, in the poem "Autumn" the poet writes:

Кўм-кўк экан, сарғайдилар япроқлар,

Оғриқ, мағлуб, туткун Шарқнинг юзидек.

Бўронларнинг кўзлариким, ўйноқлар

Ғолиб Ғарбнинг қонга тўлганкўзидек $[6,86]$.

It is a fact that the yellow leaf is a symbol of the autumn. The poet places social image on this image. In other words, the pain, the defeat, the eclipse of the 20 s of the last century is like a yellowish leaf in the Eternal East.

Қора булут тўдасиким, кўкларни

Шарқни ёпган парда янглиғ ёпмишдир.

Куз қўшини оғу тўлуғ ўқларни,

Ёз бағрига хеч саноқсиз отмишдир $[5,86]$.

The cloud in the fall, characteristic of the nature of autumn symbolizes the enemy of freedom and freedom. At the same time, the Oriental "sky" rushing towards freedom is blocking the light like a veil. The "Autumn Army" is a unique metaphor of the poet, expressing yellow leaves. Pain Poison is yellow. The "bullet-full arrows" also have a social meaning as the image of the leaves of saffron. Poet's winter poems contain traditional poetic images and innovative characters. In the poem "Snow Again" Chulpon likens snow to a white shroud. This is a new interpretation for our poetry. The poet does not stop there. He compares snow sparks to feathers:

Яна қор. Оқ кафан ўралди яна,

Яна кўк куйди ерга парларини.

Қарғанинг тиллари буралди яна,

Яна қиш чорлади “нафар”ларини $[6,95]$

Chulpan writes as:

\author{
Тўнгдиргувчи захар совуқ тунда \\ Бева-бечоралар ёмонлайлар.
}

Poetry and descriptions are based on the characteristics of winter [the poisonous cold night, the frosty, the freezing white bird], which expresses the winter scene with vivid expressions. The word "misleading" is used in the Jadid literary language. The word is derived from the verb to swallow, to freeze, to freeze [7, 239]. Hence, the word "fridge" is used synonymously for the word "freezer". Spring is coming, spring is full of feelings:

Йўқсилларни ингратгучи қиш кетиб,

Бахор келди, гулбарралар очилди.

Вахимали қиш биноси йиқилиб,

Гўзал бахор эшиклари очилди $[6,156]$.

It is obvious that after the winter visit, the awakening of the spring is awakened, the warmth of the winter cold warms up, and the nature is rejuvenated. In this sense, the "opening of the flowerpot" is a sign of spring. The poet describes the poetic description of winter melting and the retreat of cold. In other words, he is happy about the "terrible winter building collapsed" and "the beautiful spring doors have been opened." It is worth noting that there are two contrasting situations in nature.

\section{Булбулларнинг мусиқадек овози}

Рухимизга ширин озиқ берадир.

Жилва билан турса бахор шамоли,

Димоқларга шодлик иси келадир [6, 156].

In these lines, the poet draws the landscape with vividness through diagnosis and quality. After all, the sound of the nightingale will delight the hearts in the spring. Spring breeze has been diagnosed with beautiful maneuvering [smile]. The poem "Spring is coming" also impresses the poet:

Тиниқ хаво... Кўк юзинда оппоқ харир пардадек,

Оқ булутлар унда бунда ёйилганлар паришон.

Шуълаларнинг акси билан йилтиллаган игнадек

Кун тиғлари қарашларга ўткир ўткир санчилган

$$
[5,186] \text {. }
$$

The spring sky is clear. Poetry portrays this view of nature even more. The white clouds floating in the spring sky resemble a white curtain. The diagnosis is based on the diagnosis. The state of dispersion in the human being is transferred to the clouds. The sun's rays are likened to sparkling needles. As you can see, Cholpon's lines are also strings of great love for nature. In the autumn portrayal, the 
poet expresses the image of the oppressed Oriental and imposes a social context on it, but also expresses the image of the imprisoned people in their winter poems.

In the poems that spring draws the image of a living person strives to live and create. The poet's interpretations, diagnoses, and definitions serve as an effective means of expressing the harmony of nature and the lyric character. Chulpon traditions have been well maintained in the works of subsequent generations. In the poetry of Abdulla Aripov, the charming spirit is vividly portraying human suffering through the portrayal of the seasons. His poems are distinguished by the breadth of philosophical thinking, the variety and vitality of images.

In particular, in the lines of the spring, the joys and sorrows of the lyric hero are reflected in the harmony of nature. "The hardest and most difficult work in the world is to find a natural expression of thoughts, feelings and concepts, to materialize the thousands of moods, states and feelings that exist in the human brain," wrote the renowned literary critic Ibrahim Haqqulov. The more difficult it is to turn one's senses into words, the harder it is to visualize the scenes of spiritual life $[10,171]$. Indeed, in the poems of Abdulla Aripov the scenes of the spirit are beautiful and impressive, in harmony with the events of nature and the seasons. In the poem "Spring" we read:

Бахор келди гул сепин ёйиб,

Тенгсиз чирой касб этди ўлка.

Гул бахорнинг нурли жилваси

Сўнгсиз севинч бахш этди қалбга.

The spring is a joy to the hearts of the heroic lyrical hero by spreading flowers and giving the country an unparalleled beauty. This cheerful mood is exacerbated by the following passages:

Қир, адирда кўк майса-гилам,

Бутоқларда жилмаяр куртак.

Яна келди эркатой кўклам

Ёшликдай шўх, нурдай югурак.

The poet describes the season of flowering as "flower spring", "green grass", "spring". High-quality combinations such as "youthful fun", "light-hearted runner" (cheerful, juggling - adjectives) are reflected in the mood of the spring.

Тошдан тошга тўш уриб шошар-

Қаёққадир зилол шалола.

Қандай гўзал бахор тухфаси!

Адирларда қирмизи - лола.

The vitality of these lines is that they reflect beautiful and vibrant spring landscape. The charm of the spring blossoms in the heart:

Гул бахорнинг мафтуни бўлиб

Сахий қуёш сочар заррин нур.

Бахор! Дилни ром этди ўзга,

Жилвасида ёшлик хам ғурур.

In the last verses, the spirits in the poem reach its climax:

Бахор, бахор, о гўзал бахор!

Ёшлик каби дилга яқинсан.

Юрагимга шеър бўлиб кирган -

Шодлик, илхом, завққа тўкинсан

The youthful spring, with its youthful pride, inspiration, and delight, is a springtime, all of which are unique. It is understood that in this poem spring was a symbol of youth. The poet's poem "Spring is coming" resonates with the above verses:

\section{Бахор келаётир \\ Тоза, мусаффо.}

Мовий кенгликларда ўйнайди шамол.

Даралар қўйнида зангор бир хаво,

Туманли шахр ичра ётмоқлик малол.

Adorned with such qualities as spring cleanness and purity, we find a lyrical hero who wants the blue expanse of the city, tired of the bustling air. In the following verses, spring is compared to the purest breeze:

Қоялар кўксида шодмон, беқайғу

Оний умр билан солланар чечак.

Бахор - энг покиза шаббодадир бу,

Бахор - энг тоза бир шамолдир демак.

It is noteworthy that Abdulla Aripov is the only good example of spring. This wind is as sweet as a baby's breath. He gently rubs the faces of the lyric hero with a passion for spring:

Кенгликлар бағрига ураман ўзни,

Кўзимга кўрингай дилбар диёрим.

Гўдак нафасидек юпатар юзни,

Қиш бўйи интизор кутган бахорим.

In the last verses, the poet's conclusions are expressed in a manner consistent with the realities of life. After all, every season of life is fleeting, but how is it? Like spring sweet flavors or vice versa? 
Бахор-ку ўтади шамолдек шитоб,

Майли ўтажак у ва ўтар бўлсин.

Азизим, умрингда хаво бўлсин соф,

Умринг шамоллари муаттар бўлсин [9, 113]

Abdullah Aripov's poems about spring, which we have analyzed above, are beautifully illustrated by descriptions and descriptions, which combine the experiences of spring with the lyrical heroic heart. The poetry of Abdulla Aripov is heard in his poetry The poems about nature and the seasons in Tura Suleiman's creation constitute a unique artistic system. These poems add to the unique beauty, clarity and vitality of the Bakhmal Mountains. As the famous literary critic N.Rahimdjanov has rightly pointed out, nature manifests itself in the poet as "a symbol of tolerance, generosity, beauty and goodness" [11, 165].

It is well known that spring is often mentioned in our literature. However, in the poems of Tura Solomon, the vividness of intellectual clarity, emotionality and vitality are evident. There is a harmony and connection between the spring of nature and the spring of human life. The poet's well-known poem "Prayjo" confirms our opinion. In the beginning, about the title of the poem, why the title was originally called "Prayer". To whom does the poet appeal? In spring, not only the nature but also the human being are born again, and forget about the sorrows of the heart. Spring gives people new feelings, dreams, and joy. The poet asks him to give up so much life force that he will never leave it, begs and pleads. In the first lines of the poem we read:

\section{Бахор келса бошланур боғда булбул хониши}

Саъва, кумри нағмаси, суралай товланиши...[12, 2]

Indeed, spring visits can be seen in the gardens of the nightingale, the pottery, and the soft sands of sand. Because spring is such a time when everything comes to life, and a person gets the pleasure of life:

Қирларда лола сайли, қишлоқларда йилбоши:

Тўхтагай табиатдан Хаққушлар зорланиши

Бахор, кетма менинг боғимдан [12, 2].

The lines above have been used properly in the art of rituals (spring arrivals, nightingales, temples, sandals, tulips, yearlongs) and tacos ("begin", "stop"). In fact, spring arrives, according to the Eastern calendar, the beginning of the new year. This is what the poet refers to when he says "the village leader". What's more, this season, the birds' singing the "nagma" - evokes the feeling of living and creating. That is why the poet says, "Stagnation of Rights by stopping nature." Because rape is characteristic of the Arctic.

Қилмиши қинғир зотга давр қайда, даврон қайда? Ватангадо кимсага беминнат макон қайда?

Ёлғиз отга оламда ном қайда, нишон қайда?
Бахор, сенсиз сахро-ю тоғ-у тошга жон қайда?

Кетма, Бахор, менинг боғимдан [12, 2].

In these poems, the poet combines his thoughts about spring, and turns to the image of a dumb, vatango, lone horse. It combines artwork with folk articles to create images. Note that the four lines above use rhythmic Arabic script, and the rhetorical questioning is hidden in the content of the sentence. The lines reflecting the image of the human being, always striving for spring.

\section{Ўлмасликка ишора - ўланга ошиқлигим, \\ Саодатга ишора - замонга ошиқлигим}

Теранликка ишора - уммонга ошиқлигим.

Гўзалликка ишора-бўстонга ошиқлигим.

Бахор, кетма менинг боғимдан [12, 3].

In fact, 'love for the weed' is a lifelong expression. In our view, the "swallow" is a symbol of the nation, its traditions, customs and immortal values; to love her, to love and to love her, is to refer to this eternity - "immortality." "Love for the Time" is an embodiment of a life-long poet. And the person who loves life is always full of goodness and happiness. Salvage the world of love is the old truth. The lyric hero has as much depth as the oceans, and his heart is filled with beauty.

Бу кун қай бир ерда қиш, қайда хазонрезгилик,

Қайларда ёз, қайда куз, қайда жондан безгилик [12,

3].

The poem is a product of instantaneous emotions and emotions. There is no time limit. The main thing is to feel and feel in those moments what we read in the lines. After all, at some point in the world, a horrible war fire is burning, bombs exploding and guns firing. Also, there is drought, drought, drought, or vice versa: floods, homeless people, hungry and thirsty people, people who are "tired of"; Volcanoes with earthquakes and flame-flames - the mysteries of nature. It is springtime, a powerful force that can solve these mysteries.

\section{Кўкламнинг хар нафаси умрга арзигулик,}

Боғсиз, боғбонсизерда не хам қилсин эзгулик...

Кетма, Бахор, менинг боғимдан. [12,3]

Spring is the awakening season in our country, the spring is "every breath." According to the poet, our country is a garden of God. And there is a gardener who fills this "garden" for good, good and happiness.

Бахор бундай боғни сира тарк етмайди.

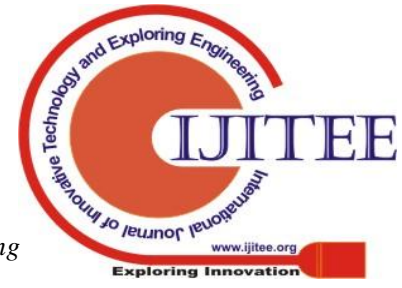


Гиёх билан қопланмиш кўхна қабр бошлари,

Майсадаги шудринглар - кимларнинг кўз ёшлари?

Бу ерда ётар отам хам узангидошлари,

Хар бахор эслар уни қавми-қариндошлари,

Бахор, кетма менинг боғимдан [12,3].

The pain in these verses are familiar to all of us. Spring is such a season that it even fills the cemetery with flowers and flowers, and breathes life into a quiet place. In this sense, these lines have a good spirit, an echo of emotion. In other words, the poet also speaks about the end of human life. The dew on the grass is an artistic finding of the poet. The poet uses it as an expression of tears and reinforces and illustrates that noble spirit.

Ёз бўйи қоргазорман, қишда бахорга зорман,

Чаманда гул бўйига интиқман, интизорман...

Куз келмай хазон бўлган севги, гулдан безорман,

Бахорсиз хам диёрсиз эл ичра беназарман,

Бахор, кетма менинг боғимдан [12,3].

In the last paragraph, the poet's ideas about spring are deepened and refined. Spring reflects the image of the Motherland. In the words of the poet, a person without spring is a homeless person. In addition, the seasons change. It also gives a new meaning to human life, and the "nature of every season" attracts it. In the above lines, T. Sulaymon expressed a longing for the good feelings in the human heart. Therefore, the longing for spring is an expression of the desire for life.

\section{RESULTS AND CONCLUSION}

1. Comparison of seasons with human life has a long history.

2. In Uzbek classical poetry, the embodiment of love and affection is a symbol of love and affection, whereas in modern poetry it is a symbol of youth and enthusiasm.

3. In Chulpon's poems, the symbolic meanings of autumn were expanded by reflection of social suffering. In particular, autumn symbolizes the crushed, shattered East.

3. The autumn and spring depictions have created the arts of tams, taz.

4. A. In the poems of Aripov, spring means a lifetime.

5. Spring, as described in the poems of Tura Suleiman, gives a sad mood to the reader. Spring, as the poet argues, is an essence that encourages not to waste life.

6. Traditional poetry is used in accordance with traditions.

Apparently, Uzbek classical and modern poetry has been able to enhance the vital and philosophical meaning of the seasons by describing the seasons. This creative process has evolved a peculiar evolution in our literature. The poems of Alisher Navoi's spring and fall seasons are mainly reflected in the emotional state of the lover and the lover.
If the image of autumn depicts the love afflicted by the Hegira, the bytes of spring reflect the meaning and beauty of human life. In Chulpon, the autumn depicting the oppressed Oriental symbol has placed social content on it. Poet's winter poems reflect the crushed and imprisoned folk image. Chulpon traditions have been well maintained in the works of subsequent generations. The poems by Abdulla Aripov reflect the image of a life-long man striving to live and create.

They share a unique view of spring that resonates with the lyrical heroic heart. The poet's interpretations, diagnoses, and definitions serve as an effective means of expressing the harmony of nature and the lyric character. The poetry of Tura Sulaymon is deeply embedded in the soul of the poet, with his sad spirit and tone. The poet looks at the life of the person as he embodies the image of spring, and the connection between the spring of nature and the spring of human life. This harmony manifests itself in every expression, confession, and dissent used by the poet.

In general, the poems we have analyzed above decorates the pages of Uzbek poetry with their unique vocabulary, poetic expressions, and integrity of poetic expression.

\section{REFERENCES}

1. Alisher Navoiy. Gurbatda g`arib shodmon bo`lmas emish. - Toshkent: Yangi asr avlodi, 2018. $-1 \ldots \mathrm{b}$.

2. Алишер Навоий.МАТ. 6-том. Фавойид ул-кибар. - Тошкент, Фан, 1990. - 566 б.

3. Алишер Навоий. Қаро кўзум. - Тошкент: Ғ.Ғулом номидаги Адабиёт ва санъат нашриёти, 1988. - 768 б.

4. Навоий асарлари луғати. - Тошкент: Ғ.Ғулом номидаги Адабиёт ва санъат нашриёти, 1972.- 782 б.

5. Чўлпон ижоди ва замонавий адабий жараён. Конференция материаллари. -Тошкент: Mashhur-press, 2018, - 326 б.

6. Чўлпон. Асарлар. I жилд. -Тошкент: Akademnashr, 2013. -372 б.

7. Улуғбек Хамдам. Янги ўзбек шеърияти. - Тошкент: Адиб, 2012, -304 б.

8. А.ОриповТанланганасарлар. 4 жилдлик. 1 жилд. Шеьрлар ва достонлар. - Т.: Ғафур Ғулом номидаги адабиёт ва санъат нашриёти, 2000 (www.ziyonetkutubxonasi). - 432 б.

9. А.Орипов. Танланган асарлар. 4 жилдлик. 2 жилд. Шеьрлар ва достонлар. Т.:Ғафур Ғулом номидаги адабиёт ва санъат нашриёти, 2001 (www.ziyonetkutubxonasi) . - 496 б.

10. Хақкулов И. Тақдир ва тафаккур. - Т.: “Шарқ" 2007 - 336 б.

11. Рахимжонов Н. Истиқлол ва бугунги адабиёт. -Тошкент: Ўқитувчи, 2012. -328 б.

12. Сулаймон Т. Гул бир ён, чаман бир ён (кўшиқлар). -Тошкент: Чўлпон, 1996. -18 б.

13. www.ziyouz.com 